J. Amer. Soc. Hort. Sci. 120(6):1087-1095. 1995.

\title{
Controlling Cropping in 'Loadel' Cling Peach Using Gibberellin: Effects on Flower Density, Fruit Distribution, Fruit Firmness, Fruit Thinning, and Yield
}

\author{
Stephen M. Southwick, Kitren G. Weis, and James T. Yeager \\ Pomology Department, University of California, Davis CA 95616 \\ Hong Zhou ${ }^{2}$ \\ Statistics Department, University of California, Davis CA 95616
}

Additional index words. plant growth regulators, fruit size, flowering, GA

\begin{abstract}
Whole-tree sprays of Release LC [predominantly gibberellic acid] (GA,) were applied in a commercial peach [Prunus perisca (L.) Batsch.] orchard in the California Central Valley on three dates from mid-June (about 90 days after full bloom $=28$ days before harvest) to late July (14 days postharvest) 1993 at 50, 75, 100, and $120 \mathrm{mg} \cdot \mathrm{Hiter}^{-1}$. Gibberellin (GA) reduced the number of flowers differentiated in 1993, thereby reducing fruit density in 1994, when sprays were applied by early July 1993. Sprays in late July did not reduce flowering and fruiting density in the following year. In 1994, there were fewer fruit located on the proximal third of the shoot after GA sprays of 75,100, and 120 mg-liter' applied on 15 June compared to hand-thinned controls, and reduction was linear with increase in GA rate. Fruit numbers in the middle and distal sections of shoots were reduced by all 15 June and some 9 July GA sprays, with fewer fruit as concentration increased. However, the distribution of fruit within shoot sections, after GA treatments during floral differentiation, expressed as a percentage of the total number of fruit along fruiting shoots, showed even fruiting compared with hand thinning. Due to reduced flowering in response to GA treatments in June and early July 1993, the hand-thinning requirement was significantly reduced, with no thinning required in 1994 from 15 June 1993 GA sprays. All sprays applied in early July resulted in $40 \%$ to $60 \%$ fewer fruit removed during thinning than the nontreated controls. Sprays in late July were ineffective. Sprays of GA applied in mid-June at 50,75, 100, and $120 \mathrm{mg} \cdot \mathrm{liter}^{-1}$ and sprays of $120 \mathrm{mg} \cdot \mathrm{liter}-\mathrm{GA}$ applied in early July ( 4 days preharvest) increased the firmness of 'Loadel' cling peach (about $26 \%$ improvement in June sprays) in 1993. The salable yield of fruit (after removal of the undersized fruit) was the same on hand thinned and on non-hand thinned trees treated with GA on 15 June at $50 \mathrm{mg}^{-1 i t e r}{ }^{-1}$. The salable yield of fruit was increased by GA sprays of 50 and $75 \mathrm{mg} \cdot$ liter $^{-1}$ applied on 9 July 1993 compared to controls. There were no differences in fruit size (by weight or diameter) among the aforementioned treatments and hand thinning. GA sprays of 75,100, and 120 mg-liter' applied on 15 June 1993 tended to reduce salable yield, but fruit size increased with decreased yield. Based on the results obtained in 1993 and 1994, we believe that Release LC has good potential for chemically thinning peaches in California.
\end{abstract}

'Loadel' cling peach is a cling peach variety that matures extra early in California. 'Loadel' is used for canning and needs thinning to ensure adequate fruit size. Premiums are paid to growers for larger (above a minimum size standard), high-quality 'Loadel' peaches. Effective chemical thinning agents could help lower costs of hand thinning, which often account for the single greatest cost of production. There have been many attempts to thin peach chemically (Batjer and Moon, 1943; Byers et al., 1984; Byers et al., 1985; Kelly, 1955; Murneek and Hibbard, 1944; Stembridge and Gambrell, 1971). Recently, sprays of monocarbamide dihydrogensulfate (Wilthin, Gowan, Yuma, Ariz.) during bloom have reduced fruit set of 'Winblo' peach and 'Fantasia' nectarine varieties, increasing fruit size without reducing yield in the southeastern United States (Myers et al., 1993).

Thinning peach flowers compared to later thinning leads to increased fruit size for an equal number of fruit on each tree (Havis, 1962; Weinberger, 1941), and fruit on thinned trees also tend to ripen earlier (Havis, 1962). Weinberger (1941) indicated that it is best to thin early maturing peach varieties growing under Georgia

Received for publication 27 Mar. 1995. Accepted for publication 10 Aug. 1995. This work was supported in part by a grant from the California Cling Peach Advisory Board and Abbott Laboratories. We acknowledge the critical review of George C. Martin and Theodore M. DeJong. The cost of publishing this paper was defrayed in part by the payment of page charges. Under postal regulations, this paper therefore must be hereby marked advertisement solely to indicate this fact. conditions as soon in the season as practical. He cautioned that bloom thinning has risks, including frost or other weather-related factors that could lower an already-reduced fruiting potential. However, even in frost-prone areas, researchers have demonstrated that bloom thinning led to favorable peach cropping and the possibility that the flowers remaining were more cold hardy (Byers and Marini, 1994; Chandler, 1907; Corgan and Widmoyer, 197 1; Edgerton, 1966; Proebsting and Mills, 1964). A problem of flower thinning has been finding an economical method to achieve consistent results, because removing flowers by hand is labor intensive and costly. Attempts to thin peaches by physical (e.g., tree shaking) or chemical means has resulted in the unsatisfactory uneven distribution of fruit along shoots (clustering) or preferential removal of larger fruit (S.M. Southwick, unpublished data).

Gibberellic acid $\left(\mathrm{GA}_{3}\right)$ inhibits flower bud differentiation in deciduous fruit (Bradley and Crane, 1960; Hull and Lewis, 1959; Li et al., 1989). Attempts to reduce flowering to facilitate hand thinning have been made previously with peach (Brown et al., 1968; Corgan and Widmoyer, 1971; Edgerton, 1966; Stembridge and Larue, 1969), sometimes resulting in delayed fruit maturation (Brown et al., 1968). Gibberellin (GA) sprays applied from late May through July to 'Patterson' apricot reduced the following season's flowering and increased fruit size compared to handthinned and nonthinned trees and eliminated the need for hand thinning in some seasons (Southwick and Fritts, 1995; Southwick et al., 1995; Southwick and Yeager, 1991). 
In this study, we report effects of pre- and postharvest sprays of GA on flowering and fruit distribution in 'Loadel' cling peach, with respect to effective application timing and dose response and relate our data to basic premises of floral differentiation control. We also examine the horticultural implications of GA treatment during floral differentiation on fruit firmness, fruit thinning, and yield.

\section{Materials and Methods}

Plant materials, experimental site, anddesign 1993, Five-yearold (planted 1989) 'Loadel' cling peaches growing on 'Lovell' rootstock were selected for these experiments in an orchard near Yuba City, Calif. The soil was classified as a Columbia silty loam. Trees were planted at $6.1 \times 6.1 \mathrm{~m}$ (269 trees/ha). The experiment was designed as a randomized complete block with five single tree replications. There were 13 treatments and 65 trees. Aqueous GA sprays (predominantly GA.,; Abbott Laboratories, North Chicago, Ill.; no surfactant or $\mathrm{pH}$ adjustment) were applied with a hand gun and pressurized to an output of 37.85 liters $\cdot \mathrm{min}^{-1}$ by a John Bean pump. Sprays were applied to wetness (about 15 to 16 liters/tree, 4000 liters $\cdot \mathrm{ha}^{-1}$ ) on 15 June (about 90 days after full bloom $=28$ days before harvest), 9 July, and 27 July 1993 at 50, 75, 100, and $120 \mathrm{mg} \cdot \mathrm{liter}^{-1}$ (phenological stages of fruit development were stage II to III transition, and stage III, respectively; Connors, 1919). Fruit were harvested by hand (13 July 1993) when they reached minimum maturity (defined by the no. 2 color disc, California Cling Peach Advisory Board).

Fruit firmness and maturity 1993 and 1994. Flesh color is the harvest maturity index as defined by the cling peach industry. Immediately before harvest ( 13 July 1993), 10 fruit were randomly collected from the periphery of each tree at 3 to $5 \mathrm{~m}$ above the soil surface. To evaluate maturity, a $0.65-\mathrm{cm}$ segment of exocarp was removed from each fruit, and a no. 2 early color disc (Magnuson engineers no. B28328; Agtron Corp., Sparks, Nev.) was used to assess whether fruit were mature and harvestable according to standard industry practices (Gradziel, 1994). Flesh firmness was measured on each fruit by removing a small exocarp segment on one side to expose the flesh. A Hunter force gauge (series L, model L30, 0-30 lb; Ametek, Hatfield, Pa.) mounted on a UC firmness stand equipped with a 7.94-mm tip was inserted into the fruit flesh.

Flower density, fruit set, and fruit distribution 1994. Five vigorous, current season's shoots were randomly selected at 3 to 5 $\mathrm{m}$ above the soil surface on each tree, and their length was measured. Each shoot was divided into three equal sections. The section closest to its point of origin was termed proximal, followed by the middle shoot section, and the final section was termed distal. Each section had a similar number of nodes. The flowers on each shoot at full bloom (11 Mar.) were counted and the data were expressed as the number of flowers per centimeter of shoot length. On 5 May, before hand thinning nonsprayed controls, fruit set was determined by counting fruit on these same shoots. Fruit density was expressed as fruit per node for each section of the shoot and as fruit per section as a percentage of the total fruit on the shoot.

Fruit thinning and early fruit weight and diameter 1994. On 5 May, 13 days before standard reference date (Davis and Davis, 1948) after fruit were hand thinned from each tree, 10 fruit were randomly sampled from around the periphery of each tree about 1.5 to $2.5 \mathrm{~m}$ from the soil surface and weighed, and their diameters were measured across the suture to determine early size differences due to thinning treatments. Based on past recommendations (Tufts, 1923), the experience of the grower, and our experience with 'Loadel', fruit thinning was broken into separate procedures. The GA-treated trees were evaluated before hand thinning and were either not thinned, thinned to eliminate clustering, or thinned to about $15 \mathrm{~cm}$ between fruit. Time required to thin individual trees was recorded as a function of treatment.

Harvest measurements (fruit size, quality, and yield) 1994. Fruit were hand harvested and weighed on 18 July 1994 when they reached minimum maturity (defined by the no. 2 disc, California Cling Peach Advisory Board). The undersized fruit were removed by passing them over a linked chain with screen size of $5.7 \mathrm{~cm}$ to eliminate small fruit. The remaining fruit were reweighed to determine the salable yield. Fifty fruit were picked randomly at harvest from each tree and weighed, and their cross-suture diameters measured. Split pits in the fruit were counted on a subsample of 25 fruit. Fruit firmness and soluble solids were determined on the other group of 25 fruit. Soluble solids were measured by randomly selecting peach halves, grinding them in a Wareing blender, and filtering the juice through cheesecloth onto a temperature-compensated hand-held refractometer ( $0 \%$ to $32 \%$; Atago N1, Tokyo).

Analyses of variance, linear regression, and Duncan's multiple range tests were performed using SAS's GLM procedure (SAS Institute, Cary, N.C.).

\section{Results}

Effects on flower density 1993 and fruit set 1994. GA sprays on 15 June and 9 July 1993 at 50, 75, 100, and $120 \mathrm{mg} \cdot$ liter $^{-1}$ reduced flower numbers per centimeter shoot length in 1994, with earlier sprays more effectively reduced flower numbers at lower concentrations (Table 1). Sprays applied on 27 July 1993 did not reduce flower numbers. Flower numbers were reduced linearly with increasing GA concentration in the 9 July treatments. Although flower density varied substantially among treatments, fruit set was not significantly different among treatments (64\% to $85 \%$; data not shown).

Fruit firmness 1993 and 1994. Fruit flesh firmness was increased after GA sprays on 50, 75, 100, and $120 \mathrm{mg} \cdot \mathrm{liter}^{-1}$ on 15 June 1993 and sprays of $120 \mathrm{mg} \cdot \operatorname{liter}^{-1}$ on 9 July (Table 1). Maturity measured as flesh color did not differ significantly as a function of GA treatment (range $90 \%$ to $100 \%$; data not shown). Fruit firmness in 1994 was increased by 50- and 75-mg-liter ${ }^{-1}$ GA sprays applied on 15 June and 9 July 1993 and by 75-mg-liter ${ }^{-1}$ GA sprays on 27 July 1993 (Table 1). Soluble solids in 1994 were not affected by 1993 GA treatments (no significant differences among treatments; data not shown).

Fruit distribution 1994. Reduced fruit density in the proximal section after the 15 June 1993 GA sprays of 75, 100, and 120 $\mathrm{mg} \cdot$ liter $^{-1}$ was highly significant and linear with increasing GA concentration (Table 2). Reduced density in middle and distal sections was also highly significant for the 15 June 1993 sprays, but not linear. Fruit density in the middle and distal sections was significantly reduced with the 9 July 1993 sprays of 120 and 100 $\mathrm{mg} \cdot$ liter $^{-1}$, respectively. An increasing (but nonsignificant) trend in reduction was seen for distribution of fruit in the middle section with the July 9 sprays when treatment means were compared to the control mean by Duncan's multiple range tests (Table 2). No significant reduction in fruit in the proximal section was found with 9 July sprays, nor with any 27 July sprays. Fruit per shoot section as a percentage of the total number of fruit on a shoot were not significantly different among treatments in either the proximal or middle sections, and were reduced in the distal shoot section only with $50 \mathrm{mg} \cdot \mathrm{liter}^{-1} \mathrm{GA}$ applied on $15 \mathrm{June}$, and $120 \mathrm{mg} \cdot \mathrm{liter}^{-1} \mathrm{GA}$ applied on 9 July.

Fruit weight and diameter (early and harvest) and split pits 1994. Because of the reduced flower and fruit number the year following GA sprays on 15 June and 9 July 1993, weight per fruit 
and fruit diameter at thinning time in 1994 were increased by GA sprays applied on 15 June 1993, increasing linearly with increasing GA concentration (Table 3). Weight per fruit and fruit diameter at thinning were also increased by GA sprays on 9 July 1993, except for the $75-\mathrm{mg} \cdot$ liter $^{-1}$ treatment, without an increase in response with increasing rate. GA sprays on 27 July 1993 did not affect weight per fruit or fruit diameter at thinning. Similarly, individual fruit weight at harvest was increased by GA sprays of 75, 100, and $120 \mathrm{mg} \cdot$ liter $^{-1}$ applied on 15 June 1993 and by sprays of 120 mg-liter ${ }^{-1}$ applied on 9 July (Table 3). Harvest fruit weight was increased by the 15 June 1993 GA sprays more effectively than by treatments made on other dates, and the increase was linear with increasing GA concentration. Although slightly less effective when applied on 9 July 1993, increasing GA concentration also elicited a linear increase in fruit weight. A similar linear response was seen in fruit diameter at harvest in the 15 June treatment group, with GA sprays of 100 and $120 \mathrm{mg} \cdot \mathrm{liter}^{-1}$ increasing fruit diameter over that of the hand-thinned control. The percentage of fruit with split pits at harvest in 1994 was not increased by 1993 GA sprays (Table 3); however, there was an increasing trend in split pits with increasing GA concentration resulting from sprays on 15 June and 9 July 1993.

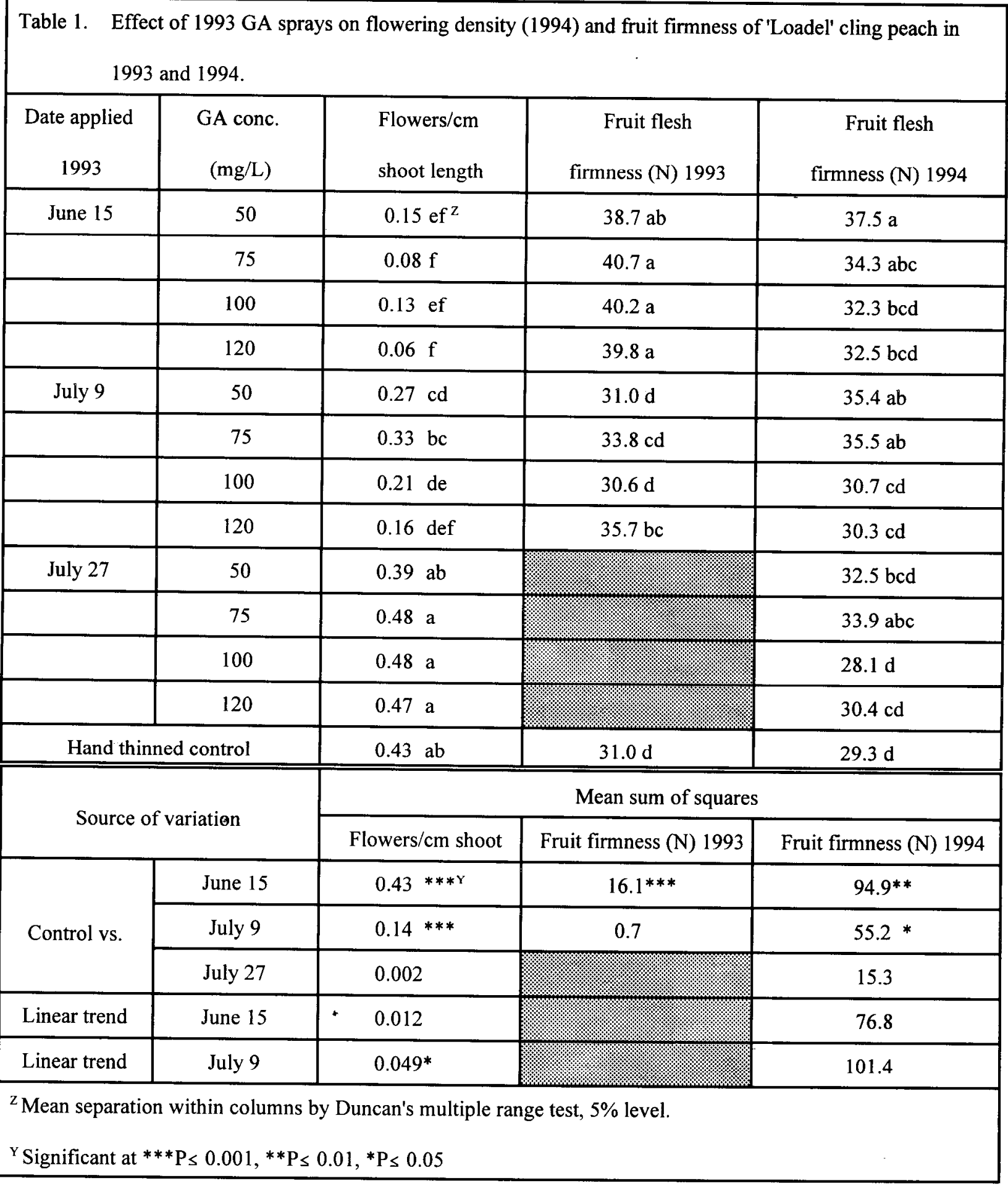


Fruit thinning 1994. As a result of the 15 June 1993 GA sprays, no hand thinning was required in 1994 (Table 4). Thinning time in 1994 and the weight and number of fruit thinned per tree were reduced by the 9 July 1993 GA sprays. GA sprays applied on 27 July 1993 had no effect on thinning time, weight, or number of fruit thinned in 1994.
Yield and undersized fruit 1994. Total yields per tree were reduced below that of hand thinned controls by GA sprays of 75 , 100, and $120 \mathrm{mg} \cdot$ liter $^{-1}$ applied on 15 June 1993 (Table 5), whereas total yield per tree was significantly higher in 1994 than handthinned trees as a result of GA sprays of $50 \mathrm{mg} \cdot \mathrm{liter}^{-1}$ applied on 15 June and 50 and $75 \mathrm{mg} \cdot \mathrm{liter}^{-1}$ applied on 9 July 1993. GA treat-

Table 2. Effect of 1993 GA sprays on fruit distribution along bearing shoots of 'Loadel' cling peach in 1994.

\begin{tabular}{|c|c|c|c|c|c|c|c|}
\hline \multirow[b]{2}{*}{$\begin{array}{c}\text { Date applied } \\
1993\end{array}$} & \multirow[b]{2}{*}{$\begin{array}{l}\text { GA } \\
\text { conc. } \\
(\mathrm{mg} / \mathrm{L})\end{array}$} & \multicolumn{6}{|c|}{ Distribution of fruit along shoots $x$} \\
\hline & & $\begin{array}{l}\text { Fruits/node } \\
\text { (proximal) }\end{array}$ & $\begin{array}{l}\text { Fruits/ } \\
\text { section } \\
\text { \% of total } \\
\text { (proximal) }\end{array}$ & $\begin{array}{l}\text { Fruits/node } \\
\text { (middle) }\end{array}$ & $\begin{array}{l}\text { Fruits/ } \\
\text { section } \\
\text { \% of total } \\
\text { (middle) }\end{array}$ & $\begin{array}{c}\text { Fruits/node } \\
\text { (distal) }\end{array}$ & $\begin{array}{l}\text { Fruits/ } \\
\text { section } \\
\text { \% of total } \\
\text { (distal) }\end{array}$ \\
\hline \multirow[t]{4}{*}{ June 15} & 50 & 0.38 bcde $^{2}$ & $36.5 \mathrm{a}$ & $0.22 \mathrm{de}$ & $26.6 \mathrm{a}$ & $0.09 \mathrm{bcd}$ & $36.9 \mathrm{c}$ \\
\hline & 75 & 0.21 ef & $34.8 \mathrm{a}$ & $0.10 \mathrm{e}$ & $26.2 \mathrm{a}$ & $0.05 \mathrm{~d}$ & $40.0 \mathrm{abc}$ \\
\hline & 100 & $0.24 \mathrm{def}$ & $33.1 \mathrm{a}$ & $0.07 \mathrm{e}$ & $29.0 \mathrm{a}$ & $0.10 \mathrm{bcd}$ & $37.9 \mathrm{bc}$ \\
\hline & 120 & $0.10 \mathrm{f}$ & $33.2 \mathrm{a}$ & $0.03 \mathrm{e}$ & $28.6 \mathrm{a}$ & $0.05 \mathrm{~d}$ & $38.2 \mathrm{bc}$ \\
\hline \multirow[t]{4}{*}{ July 9} & 50 & $0.47 \mathrm{bcd}$ & $31.2 \mathrm{a}$ & $0.40 \mathrm{bcd}$ & $27.0 \mathrm{a}$ & $0.20 \mathrm{abcd}$ & $41.8 \mathrm{ab}$ \\
\hline & 75 & $0.58 \mathrm{abc}$ & $31.8 \mathrm{a}$ & $0.43 \mathrm{bcd}$ & $29.2 \mathrm{a}$ & $0.08 \mathrm{~cd}$ & $39.0 \mathrm{abc}$ \\
\hline & 100 & 0.37 cde & $34.4 \mathrm{a}$ & $0.34 \mathrm{~cd}$ & $28.1 \mathrm{a}$ & $0.07 \mathrm{~d}$ & $37.5 \mathrm{bc}$ \\
\hline & 120 & 0.39 bcde & $33.5 \mathrm{a}$ & $0.25 \mathrm{de}$ & $30.5 \mathrm{a}$ & $0.08 \mathrm{~cd}$ & $36.0 \mathrm{c}$ \\
\hline \multirow[t]{4}{*}{ July 27} & 50 & $0.63 \mathrm{ab}$ & $32.7 \mathrm{a}$ & $0.75 \mathrm{a}$ & $27.4 \mathrm{a}$ & $0.26 \mathrm{a}$ & $39.9 \mathrm{abc}$ \\
\hline & 75 & $0.40 \mathrm{bcde}$ & $32.0 \mathrm{a}$ & $0.58 \mathrm{ab}$ & $28.2 \mathrm{a}$ & $0.23 \mathrm{ab}$ & $39.8 \mathrm{abc}$ \\
\hline & 100 & $0.46 \mathrm{bcd}$ & $32.1 \mathrm{a}$ & $0.55 \mathrm{abc}$ & $27.6 \mathrm{a}$ & $0.17 \mathrm{abcd}$ & $40.3 \mathrm{abc}$ \\
\hline & 120 & $0.73 \mathrm{a}$ & $30.7 \mathrm{a}$ & $0.74 \mathrm{a}$ & $25.9 \mathrm{a}$ & $0.14 \mathrm{abcd}$ & $43.4 \mathrm{a}$ \\
\hline \multicolumn{2}{|c|}{ Hand thinned control } & $0.56 \mathrm{abc}$ & $31.9 \mathrm{a}$ & $0.51 b c$ & $26.6 \mathrm{a}$ & $0.22 \mathrm{abc}$ & $41.5 \mathrm{ab}$ \\
\hline \multirow{2}{*}{\multicolumn{2}{|c|}{ Source of variation }} & \multicolumn{6}{|c|}{ Mean sum of squares } \\
\hline & & \multicolumn{2}{|c|}{ Fruits/node (proximal) } & \multicolumn{2}{|c|}{ Fruits/node (middle) } & \multicolumn{2}{|c|}{ Fruits/node (distal) } \\
\hline \multirow{3}{*}{ Control vs. } & June 15 & \multicolumn{2}{|c|}{$0.431 * * * Y$} & \multicolumn{2}{|c|}{$0.660 * * *$} & \multicolumn{2}{|c|}{$0.082^{* *}$} \\
\hline & July 9 & \multicolumn{2}{|c|}{0.046} & \multicolumn{2}{|c|}{0.098} & \multicolumn{2}{|c|}{$0.048^{*}$} \\
\hline & July 27 & \multicolumn{2}{|c|}{0.0002} & \multicolumn{2}{|c|}{0.084} & \multicolumn{2}{|c|}{0.001} \\
\hline Linear trend & June 15 & \multicolumn{2}{|c|}{$0.165^{*}$} & \multicolumn{2}{|c|}{0.088} & \multicolumn{2}{|c|}{0.008} \\
\hline \multicolumn{8}{|c|}{$\begin{array}{l}{ }^{\mathrm{z}} \text { Mean separation within columns by Duncan's multiple range test, } 5 \% \text { level. } \\
\mathrm{Y}^{\mathrm{Y}} \text { Significant at }{ }^{* * *} \mathrm{P} \leq 0.001{ }^{* *} \mathrm{P} \leq 0.01{ }^{*} \mathrm{P} \leq 0.05\end{array}$} \\
\hline
\end{tabular}


merits-applied on 15 June more effectively decreased the total yields per tree than the July treatments. There was a linear reduction in total yields per tree with increasing GA concentration in response to the 9 July 1993 GA treatments. Other GA treatments did not differ in total yield from the hand-thinned treatments.

Salable yields per tree in 1994 were decreased by GA sprays of 75,100, and $120 \mathrm{mg} \cdot$ liter $^{-1}$ applied on 15 June 1993 compared with all other rate-date treatment combinations (Table 5) partly resulting from the increase in percentage of undersized fruit and fruit clustering (data not shown; clusters were not hand thinned) in these treatments. No other GA treatment changed the percentage of undersized fruit. The reduced salable yields for the 15 June 1993 treatments was linear with increasing GA concentration. Salable yields in 1994 were increased by GA sprays of 50 and $75 \mathrm{mg} \cdot \mathrm{liter}^{-1}$ applied on 9 July 1993. Other GA sprays did not affect salable yields per tree.

\section{Discussion}

Peach flowers are borne axillary to the primary leaf or to secondary or tertiary lateral structures (scales or leaves) on 1-yearold shoots (Dorsey, 1935). The nodes on the proximal portion of the shoot are initiated in April and May and, as the shoot bud elongates nodes continue to initiate, until the shoot has achieved a final length of about $60 \mathrm{~cm}$ with about 30 nodes, depending on irrigation or rainfall. Extension shoot growth in the Central Valley of California occurs from late March through August or September. Floral buds initiate acropetally as the shoot grows out, and floral parts are initiated in 'Elberta' peach beginning in early August in Davis, Calif. (Tufts and Morrow, 1925), although distinctive floral bud scales may be the first floral bud part identifiable in early June in Illinois for 'Elberta' peach (Dorsey, 1935). Floral differentiation continues during August and September (Gur, 1985). The long period of floral transition offers potential flexibility in thinning buds otherwise destined to become floral, as the identifiable period of sensitivity to GA-induced flower bud inhibition encompasses as much as 7 weeks.

Early reduction of flower buds and fruit by bloom thinning maximizes the tree's ability to size fruit (Weinberger, 1941). Foliarly applied $\mathrm{GA}_{3}$ reduced return bloom on proximal nodes in 'Redkist' peach beginning in late May, when 12 to 14 nodes were present (Ward, 1993), or 30 days after full bloom (Byers et al., 1990). Subsequent GA sprays through July reduced bloom in proximal, middle, and distal sections, up to $82 \%, 50 \%$, and $46 \%$, respectively, with reduction directly proportional to $\mathrm{GA}_{3}$ concentration, and without affecting node density or shoot length (Ward, 1993). Sprays late in the summer with high doses of $\mathrm{GA}_{3}$ may thin flower buds by killing them (Painter and Stembridge, 1972). The action of gibberellin in reducing potentially floral buds is such that transition into a floral state is inhibited by GA before the inductive period (Bemier, 1988; Clanet et al., 1976; Li et al., 1989; Painter and Stembridge, 1972). In our study, numbers of fruit per node in the proximal section declined with increasing concentration of GA in a significant linear response with the 15 June 1993 treatments. The linear nature of the response is a new characteristic of flower bud density reduction by GA that has not been reported by previous researchers (Byers et al., 1990; Clanet et al., 1976; Hull and Lewis, 1959; Ward, 1993). The percentages of fruit in the proximal and middle sections did not vary from the control with respect to the percentage of the total number of fruit on the shoot. Peach growers

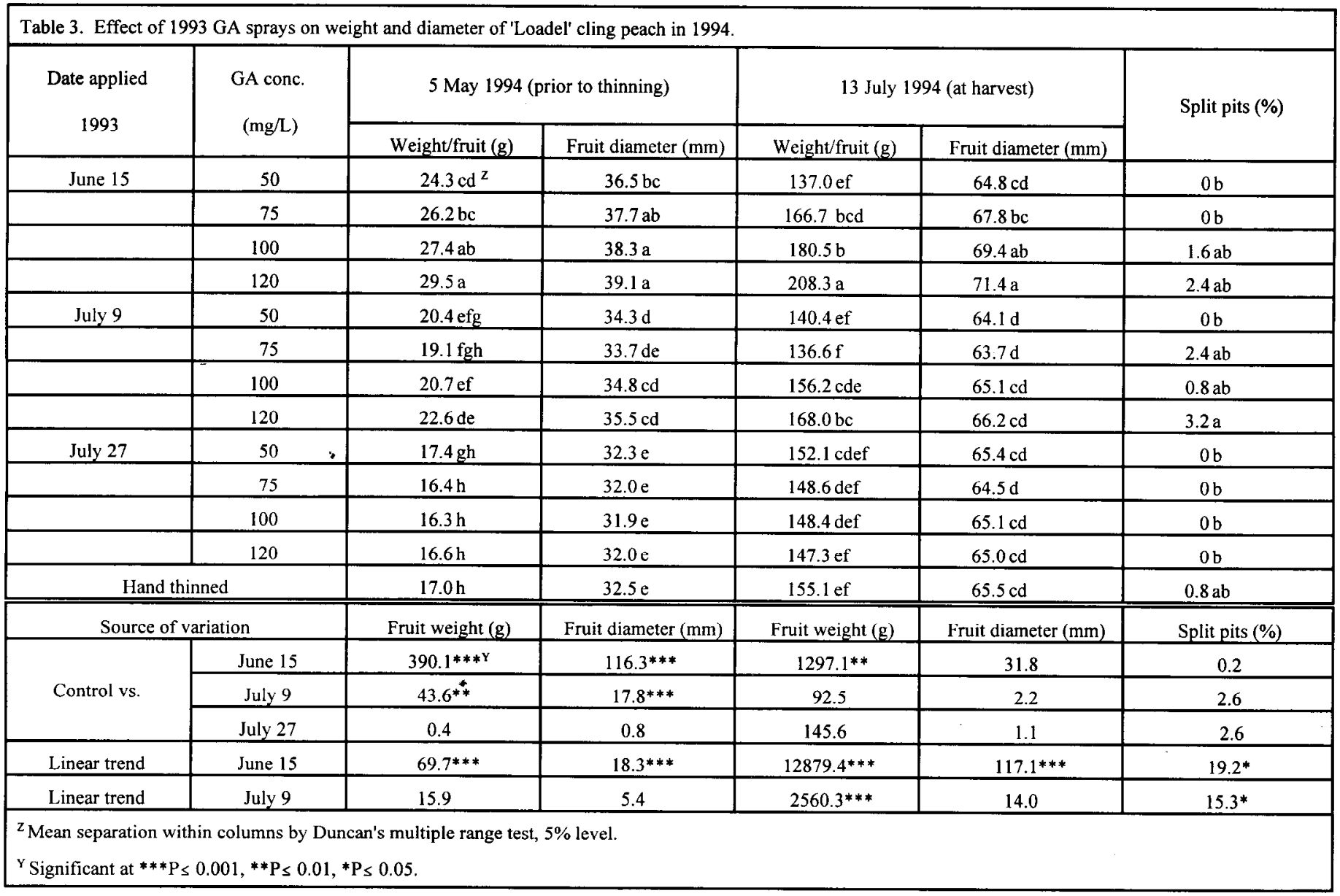


Table 4. Effect of 1993 GA sprays on the weight and number of fruits thinned and thinning time in 1994.

\begin{tabular}{|c|c|c|c|c|c|}
\hline $\begin{array}{c}\text { Date applied } \\
1993\end{array}$ & $\begin{array}{l}\text { GA conc. } \\
(\mathrm{mg} / \mathrm{L})\end{array}$ & $\begin{array}{l}\text { Thinning } \\
\text { time/tree (min) }\end{array}$ & $\begin{array}{l}\text { Reduction in } \\
\text { thinning time } \\
(\%)\end{array}$ & $\begin{array}{c}\text { Weight of } \\
\text { thinned fruits/tree } \\
(\mathrm{kg})\end{array}$ & $\begin{array}{c}\text { No. of thinned } \\
\text { fruits/tree }\end{array}$ \\
\hline \multirow[t]{4}{*}{ June 15} & 50 & 0 & 100 & 0 & 0 \\
\hline & 75 & 0 & 100 & 0 & 0 \\
\hline & 100 & 0 & 100 & 0 & 0 \\
\hline & 120 & 0 & 100 & 0 & 0 \\
\hline \multirow[t]{4}{*}{ July 9} & 50 & $15.0 \mathrm{a}^{\mathrm{z}}$ & 30 & $30.3 \mathrm{~b}$ & $1749 \mathrm{~b}$ \\
\hline & 75 & $17.0 \mathrm{a}$ & 20 & $31.1 \mathrm{~b}$ & $1858 \mathrm{~b}$ \\
\hline & 100 & $13.2 \mathrm{a}$ & 38 & $24.2 \mathrm{~b}$ & $1260 \mathrm{~b}$ \\
\hline & 120 & $15.1 \mathrm{a}$ & 29 & $27.3 \mathrm{~b}$ & $1390 \mathrm{~b}$ \\
\hline \multirow[t]{4}{*}{ July 27} & 50 & $19.8 \mathrm{a}$ & 7 & $49.1 \mathrm{a}$ & $3161 \mathrm{a}$ \\
\hline & 75 & $22.6 \mathrm{a}$ & -6 & $51.4 \mathrm{a}$ & 3218 a \\
\hline & 100 & $17.8 \mathrm{a}$ & 17 & $53.5 \mathrm{a}$ & $3665 \mathrm{a}$ \\
\hline & 120 & $20.6 \mathrm{a}$ & 4 & $49.5 \mathrm{a}$ & $3300 \mathrm{a}$ \\
\hline \multicolumn{2}{|c|}{ Hand thinned control } & $21.4 \mathrm{a}$ & 0 & $50.5 \mathrm{a}$ & $3147 \mathrm{a}$ \\
\hline \multirow{2}{*}{\multicolumn{2}{|c|}{ Source of variation }} & \multicolumn{4}{|c|}{ Mean sum of squares } \\
\hline & & $\begin{array}{l}\text { Thinning } \\
\text { time/tree (min) }\end{array}$ & & $\begin{array}{c}\text { Weight of } \\
\text { thinned fruits/tree }\end{array}$ & $\begin{array}{l}\text { No thinned } \\
\text { fruits/tree }\end{array}$ \\
\hline \multirow{2}{*}{ Control vs. } & June 15 & $0.4^{* * * \mathrm{Y}}$ & & $1985.0^{* * *}$ & $10,018,174.5^{* *}$ \\
\hline & July 9 & $0.01 * * *$ & & 0.6 & $143,938.3$ \\
\hline${ }^{\mathrm{z}}$ Mean separat & within colur & $\begin{array}{l}\text { by Duncan's mult } \\
\leq 0.01,{ }^{*} \mathrm{P} \leq 0.00\end{array}$ & \multicolumn{2}{|c|}{${ }^{\mathrm{z}}$ Mean separation within columns by Duncan's multiple range test, $5 \%$ level. } & \\
\hline
\end{tabular}

use hand thinning to reduce the number of fruit, increasing the leafto-fruit ratio. Simultaneously, growers space the fruit along shoots, minimizing fruit clustering and associated problems (e.g., disease outbreak). The relatively even distribution of fruit along shoots resulting from GA treatment was unexpected but welcome because the treatment nearly mimicked the spatial distribution of fruit found after hand thinning. The slight, but significant, reduc- tion in the percentage of total number of fruit found in the distal section after the 50-mg.liter ${ }^{-1}$ GA treatment of 15 June and 120$\mathrm{mg} \cdot$ liter $^{-1} \mathrm{GA}$ treatment of 9 July is not great enough to pose problems for commercial growers. The reduced the numbers of fruit per node in all shoot sections were highly significant with a tendency toward an inverse relationship between fruit numbers per node and concentration of GA, providing tangible evidence of the 
Table 5. Effect of 1993 GA sprays on yield and percentage of undersized fruits produced on 'Loadel' cling peach trees in 1994.

\begin{tabular}{|c|c|c|c|c|}
\hline Date applied 1993 & $\begin{array}{l}\text { GA conc. } \\
(\mathrm{mg} / \mathrm{L})\end{array}$ & $\begin{array}{l}\text { Total yield } \\
\text { (kg/tree) }\end{array}$ & $\begin{array}{c}\text { Salable yield } \\
\text { (kg/tree) }\end{array}$ & $\begin{array}{l}\text { Undersized } \\
\text { fruits (\%/tree) }\end{array}$ \\
\hline \multirow[t]{4}{*}{ June 15} & 50 & $149.8 \mathrm{ab}^{\mathrm{z}}$ & $114.5 \mathrm{abc}$ & $23.6 \mathrm{a}$ \\
\hline & 75 & $90.4 \mathrm{ef}$ & $71.7 \mathrm{~d}$ & $22.3 \mathrm{a}$ \\
\hline & 100 & $66.5 \mathrm{f}$ & $51.3 \mathrm{~d}$ & $23.5 \mathrm{a}$ \\
\hline & 120 & $67.2 \mathrm{f}$ & $51.9 \mathrm{~d}$ & $22.7 \mathrm{a}$ \\
\hline \multirow[t]{4}{*}{ July 9} & 50 & $155.1 \mathrm{ab}$ & $131.7 \mathrm{a}$ & $15.0 \mathrm{bc}$ \\
\hline & 75 & $161.6 \mathrm{a}$ & $132.0 \mathrm{a}$ & $18.4 \mathrm{ab}$ \\
\hline & 100 & $145.1 \mathrm{abc}$ & $125.3 \mathrm{ab}$ & $13.3 \mathrm{bc}$ \\
\hline & 120 & $133.3 \mathrm{bcd}$ & $117.2 \mathrm{abc}$ & $11.9 \mathrm{c}$ \\
\hline \multirow[t]{4}{*}{ July 27} & 50 & $113.0 \mathrm{de}$ & $95.2 \mathrm{c}$ & $15.8 \mathrm{bc}$ \\
\hline & 75 & $120.6 \mathrm{~cd}$ & $106.6 \mathrm{bc}$ & $11.4 \mathrm{c}$ \\
\hline & 100 & $145.2 \mathrm{abc}$ & $123.9 \mathrm{ab}$ & $14.6 \mathrm{bc}$ \\
\hline & 120 & $138.0 \mathrm{abcd}$ & $118.6 \mathrm{abc}$ & $14.1 \mathrm{bc}$ \\
\hline \multicolumn{2}{|c|}{ Hand thinned control } & $121.5 \mathrm{~cd}$ & $104.9 \mathrm{bc}$ & $13.7 \mathrm{bc}$ \\
\hline \multirow{2}{*}{\multicolumn{2}{|c|}{ Source of variation }} & \multicolumn{3}{|c|}{ Mean sum of squares } \\
\hline & & Yield (kg/tree) & $\begin{array}{l}\text { Salable yield } \\
(\mathrm{kg} / \mathrm{tree})\end{array}$ & $\begin{array}{l}\text { Undersized } \\
\text { fruits }(\% / \text { tree })\end{array}$ \\
\hline \multirow{3}{*}{ Control vs. } & June 15 & $3143.7^{* * Y}$ & $4226.7 * * *$ & $345.4^{* * *}$ \\
\hline & July 9 & $2978.0^{* *}$ & 1882.2 & 3.3 \\
\hline & July 27 & 236.9 & 153.6 & 0.2 \\
\hline Linear trend & June 15 & $19,259.6$ & $11,280.1^{* * *}$ & 0.5 \\
\hline Linear trend & July 9 & $1617.3^{*}$ & 609.0 & 49.7 \\
\hline \multicolumn{5}{|c|}{$\begin{array}{l}{ }^{\mathrm{z}} \text { Mean separation within columns by Duncan's multiple range test, } 5 \% \text { level. } \\
{ }^{\mathrm{Y}} \text { Significant at }{ }^{* * *} \mathrm{P} \leq 0.001,{ }^{*} \mathrm{P} \leq 0.01,{ }^{*} \mathrm{P} \leq 0.05\end{array}$} \\
\hline
\end{tabular}

value of gibberellin as a replacement for hand thinning in cling peach. By choosing an appropriate time and concentration combination to take advantage of a fairly wide window of opportunity with respect to sensitivity, hand thinning should be reduced to a minimum.

Increased fruit firmness in the same year as treatment has been demonstrated in sweet cherry through effective use of GA, (Proeb- sting et al., 1973) and GA, treatment to increase firmness in cherry has become commercial practice in much of the western United States and Canada. Fruit firmness was improved in 1993 by preharvest GA sprays in 'Loadel' cling peach. Interestingly, fruit firmness was also increased in 1994 as a function of 1993 GA treatments. Reducing flower numbers reduced the initial number of fruit present. Fewer competing sinks early in fruit development 
could have increased cell number (Ho, 1988) in remaining fruit. Bain and Robertson (195 1) found that large apples had more cells than smaller fruit from the same tree, and Westwood et al. (1967) found that large apples from light-blooming trees had more cells than smaller fruit from heavier-blooming trees, as did fruit that were chemically thinned early in the season. The ratio of cell wall to cell volume could have been increased in fruit from GA-treated trees due to greater cell numbers, leading to improved fruit firmness. Improved fruit firmness may lead to improved quality and storage life of the processed product and reduced fruit damage or decay. Additional experiments are needed to demonstrate these possible beneficial effects.

Results from 1994 clearly show that the number of flowers in 'Loadel' peach can be reduced by GA sprays applied on 15 June and 9 July 1993. No measurable negative effects were found. Percentage fruit set was not reduced by GA treatment and, consequently, the reduction in flowers led to fewer fruit present at thinning time as a result of the June and early July GA treatments. In fact, the 1993 June treatments required no hand thinning in 1994. The distribution of fruit along shoots after the 15 June and 9 July 1993 GA spray treatments was like that found after hand thinning. Fruit clusters persisting after GA treatment should probably be broken up at thinning to ensure uniform fruit sizing. Palmer et al. (1991) showed that partial tree flower thinning was as effective as whole-tree thinning in reducing crop and increasing fruit size. In theory, assimilate is free to move from one side of the tree to the other to support the growth and development of the fruit. Hansen and Christensen (1974) found no significant differences in yield and fruit size from a uniform or nonuniform fruit distribution. Marini and Sowers (1994) validated that fruit size depends on the leaf-to-fruit ratio and that leaves near fruit strongly contribute to maximizing fruit size. In our work, we left clusters of peaches rather than breaking them. In contradiction to results seen in Hansen and Christensen's work on apples, we believe that 'Loadel' peaches did not size as well because of the clustering, leading to more undersized fruit in the 15 June $1993 \mathrm{GA}$ treatments. We also noted a tendency toward increased vegetative growth as a result of reduced fruit numbers from GA treatments of 15 June 1993, as reported by Palmer et al. (1991).

Reduced numbers of flowers resulting from the prior season's GA spray treatments coupled with fruit set like that found in nontreated controls led to improved fruit size at thinning. Measuring fruit size at a predetermined reference date helps cling peach growers assess how many fruit should be removed to maximize fruit size-crop load relations (Davis, 1950; Davis and Davis, 1948). Larger fruit at reference size (date) following GA treatment suggests that growers may be able to leave more fruit on trees leading to higher yields of marketable fruit as demonstrated in these studies.

At harvest, total and salable yields were not reduced by GA concentrations of 50 and $75 \mathrm{mg} \cdot$ liter $^{-1}$ applied in mid-June to early July under California conditions for this variety. Fruit sizes from those GA treatments were not different from hand-thinned fruit sizes. These results represent the best possible response because thinning activity is reduced without reducing yield or fruit size. The increase in yield following GA treatment over hand thinning is similar to responses measured previous17 in apricot (Southwick and Fritts, 1995; Southwick and Yeager, 1995).

In conclusion, there were no measurable detrimental effects of GA treatment. The advantages of the GA spray thinning program include 1) along period with regard to spray timing, 2) temperature effects that are less likely to contribute to variation because daily temperatures are consistent during this part of the season in
California, 3) an even distribution of fruit along shoots, 4) the possibility of improved yields and fruit size with reduced or no hand thinning, and 5) spray treatments that are apparently environmentally safe. We estimate the savings in hand-thinning costs from the most effective GA treatments (50 and $75 \mathrm{mg} \cdot \mathrm{liter}^{-1}$ applied 15 June and 9 July) to be $\$ 75.00$ to $\$ 125.00 /$ acre for 'Loadel' based on the current price of GA and hand thinning costs. Commercial use of GA for chemically thinning stone fruit in California is under development.

\section{Literature Cited}

Bain, J.M. and R.N. Robertson. 195 1. The physiology of growth of apple fruits. I. Austral. J. Sci. Res. 4:75-91.

Batjer, L.P. and H.H. Moon. 1943. Thinning apples and peaches with blossom-removal sprays. Proc. Amer. Soc. Hort. Sci. 43:43-46.

Bernier, G. 1988. The control of floral evocation and morphogenesis. Annu. Rev. Plant Physiol. Plant Mol. Biol. 39:175-219.

Bradley, M.V. and J. Crane. 1960. Gibberellin-induced inhibition of bud development in some species of Prunus. Science 131:825-826.

Brown, L.C., J.C. Crane, and J.A. Beutel. 1968. Gibberellic acid reduces cling peach flower buds. Calif. Agr. 22:7-8.

Byers, R.E., D.H. Carbaugh, and C.N. Presley. 1990. The influence of bloom thinning and GA, sprays on flower bud numbers and distribution in peach trees. J. Hort. Sci. 65: 143-150.

Byers, R.E., C.G. Lyons, Jr., T.B. DelValle, J.A. Barden, and R.W. Young. 1984. Peach fruit abscission by shading and photosynthetic inhibition. HortScience 19:649-651.

Byers, R.E., C.G. Lyons, Jr., K.S. Yoder, J.A. Barden, and R.W. Young. 1985. Peach and apple thinning by shading and photosynthetic inhibition. J. Hort. Sci. 60:465-472.

Byers, R.E. and C.G. Lyons, Jr. 1985. Peach flower thinning and possible sites of action of desiccating chemicals. J. Amer. Soc. Hort. Sci. 100:662-667.

Byers, R.E. and R.P. Marini. 1994. Influence of blossom and fruit thinning on peach flower bud tolerance to an early spring freeze. HortScience 29:146-148.

Chandler, W.H. 1907. The winter killing of peach buds as influenced by previous treatment. Mo. Agr. Expt. Sta. Bul. 74.

Clanet, H. and J. C. Salles. 1976. Etude de l'action de l'acide gibberellique surle developpement des ébauches florales chez le pêcher: conséquences practiques. Ann. Amélior. Pl. 26:285-294.

Connors, C.H. 1919. Growth of fruits of the peach. N.J. Agr. Expt. Sta. Annu. Rpt. 41:82.

Corgan, J.N. and F.B. Widmoyer. 1971. The effects of gibberellic acid on flower differentiation, date of bloom, and flower hardiness of peach. J. Amer. Soc. Hort. Sci. 96:54-57.

Davis, L.D. 1950. Size in canning peaches. The relation between the diameter at harvest and the growth made after reference date. Proc. Amer. Soc. Hort. Sci. 55:212-216.

Davis, L.D. and M.M. Davis. 1948. Size in canning peaches. The relation between the diameter of cling peaches early in the season and at harvest. Proc. Amer. Soc. Hort. Sci. 51:225-230.

Dorsey, M.J. 1935. Nodal development of the peach shoot as related to fruit bud formation. Proc. Amer. Soc. Hort. Sci. 33:245-247.

Edgerton, L.J. 1966. Some effects of gibberellin and growth retardants on bud development and cold hardiness of peach. Proc. Amer. Soc. Hort. Sci. 88: 197-203.

Gradziel, T.M. 1994. Changes in susceptibility to brown rot with ripening in three clingstone peach genotypes. J. Amer. Soc. Hort. Sci. 119:101105.

Gur, A. 1985. Rosaceae-Deciduous fruit trees. In: A.H. Halevy (ed.). Handbook of flowering. vol. 1. CRC, Boca Raton, Fla. p. 355-389.

Hansen, P. and J.V. Christensen. 1974. Fruit thinning. III. Translocation of ${ }^{14} \mathrm{C}$ assimilates to fruit from near and distant leaves in the apple 'Golden Delicious'. Hort. Res. 14:41-45.

Havis, A.L. 1962. Effects of time of fruit thinning of Redhaven peach. Proc. Amer. Soc. Hort. Sci. 80:172-176.

Ho, L.C. 1988. Metabolism and compartmetation of imported sugars in 
sink organs in relation to sink strength. Annu. Rev. Plant Physiol. Plant Mol. Biol. 39:355-378.

Hull, J., Jr., and L.N. Lewis. 1959. Response of one-year-old cherry and mature bearing cherry, peach and apple trees to gibberellin. Proc. Amer. Soc. Hort. Sci. 74:93-100.

Kelly, V.W. 1955. Time of application of naphthaleneacetic acid for fruit thinning of the peach in relation to June drop. Proc. Amer. Soc. Hort. Sci. 66:70-72.

Li, S.-H., C. Bussi, J. Hugard, and H. Clanet. 1989. Critical period of flower bud induction in peach trees associated with shoot length and bud position. Gartenbauwissenschaft 54:49-53.

Marini, R.P. and D.L. Sowers. 1994. Peach fruit weight is influenced by crop density and fruiting shoot length but not position on the shoot. J. Amer. Soc. Hort. Sci. 119 180-184.

Murneek, A.E. and A.D. Hibbard. 1944. Results of thinning peaches with elgetol and switches. Proc. Amer. Soc. Hort. Sci. 45:69-71.

Myers, S.C., A. King, and A.T. Savelle. 1993. Bloom thinning of 'Winblo' peach and 'Fantasia' nectarine with monocarbamide dihydrogensulfate. HortScience 28:616-617.

Painter, J.W. and G.E. Stembridge. 1972. Peach flowering response as related to time of gibberellin application. HortScience 7:389-390.

Palmer, J.W., Y.-L. Cai, and Y. Edjamo. 1991. Effect of part-tree flower thinning on fruiting, vegetative growth and leaf photosynthesis in 'Cox’s Orange Pippin' apple. J. Hort Sci. 66:319-325.

Proebsting, E.L., Jr., and H.H. Mills. 1964. Gibberellin-induced hardiness responses in Elberta peach flower buds. Proc. Amer. Soc. Hort. Sci. 85:134-140.

Proebsting, E.L., Jr., G.H. Carter, andH.H. Mills. 1973. Quality improvement in canned 'Rainier' cherries (Prunus avium L.) with gibberellic acid. J. Amer. Soc. Hort. Sci. 98:334-336.

Southwick, SM. and R. Fritts. 1995. Commercial chemical thinning of stone fruit in California by gibberellins to reduce flowering. Acta Hort. (In press.)

Southwick, S.M. and J.T. Yeager. 1991. Effects of postharvest gibberellic acid application on return bloom of 'Patterson' apricot. Acta Hort. 293:459-466.

Southwick, S.M. and J.T. Yeager. 1995. Use of gibberellin formulation 3067 for chemical thinning in 'Patterson' apricot. Acta Hort. (In press.) Southwick, SM., J.T. Yeager, and H. Zhou. 1995. Flowering and fruiting in 'Patterson' apricot (Prunus armeniaca) in response to postharvest application of gibberellic acid. Sci. Hort. 60:267-277.

Stembridge, G.E. and J.H. Lame. 1969. The effect of potassium gibberellate on flower bud development in Redskin peach. J. Amer. Soc. Hort. Sci. 94:492-495.

Stembridge, G.E. and C.E. Gambrell. 197 1. Thinning peaches with bloom and post-bloom applications of 2-chloroethyl phosphonic acid. J. Amer. Soc. Hort. Sci. 96:7-10

Tufts, W.P. 1923. Thinning deciduous fruits. Univ. Calif. Agr. Expt. Sta. Circ. no. 258.

Tufts, W.P. and E.B. Morrow. 1925. Fruit-bud differentiation in deciduous fruits. Hilgardia 1:1-14.

Ward, D.L. 1993. Reducing flower bud density of 'Redkist' peach with GA,. MA thesis. Southern Illinois Univ., Carbondale.

Weinberger, J.H. 1941. Studies on time for peach thinning from blossoming to maturity. Proc. Amer. Soc. Hort. Sci. 38:137-140.

Westwood, M.N., L.P. Batjer, and H.D. Billingsley. 1967. Cell size, cell number, and fruit density of apples as related to fruit size, position in cluster, and thinning method. Proc. Amer. Soc. Hort. Sci. 91:51-62. 